\title{
Environmental Ethics: The Virtuous Way
}

\author{
Carlo Alvaro* \\ Department of Social Science, New York City College of Technology, USA
}

Submission: January 08, 2018, Published: August 09, 2018

"Corresponding author: Carlo Alvaro, Department of Social Science, New York City College of Technology, USA; Email: philonew@gmail.com

Abstract

Environmental ethics, among other things, is concerned with our attitude toward nature. By nature here I don't mean anything other than the waters, the trees, non-human animals-the environment. It is, moreover, concerned about what Rosalind Hurst house call "the belief that a fairly radical change in the way we engage with nature is imperative." In what follows, I want to propose a virtue-oriented approach to environmental. My aim is to begin a discussion about the potential advantages of adopting a virtue-based approach to our outlook toward the environment.

Keywords: Environmental Ethics; Aristotle; Virtue; Utilitarianism; Kant

\section{Introduction}

There are three major ethics theories that attempt to specify and justify our moral behavior: utilitarianism, deontology, and virtue ethics [1]. Utilitarianism (which is a form of consequentialism) has its origin in Epicureanism. However, it was Jeremy Bentham (1748-1842) and John Stuart Mill (18061873) who developed and refined it in the modern world. There are different kinds of utilitarianism. But essentially, utilitarianism argues that no moral act or rule is intrinsically right or wrong. Killing, stealing, lying, keeping promises, donating money to the poor, or helping the elderly cross the street is neither right nor wrong as such. They may become right or wrong based on their consequences. If the consequences of my killing a person turns out to produce the greatest good for the greatest number of beings, and possibly the least amount of evil, then utilitarians would deem that act right [2]. Or, if the consequences of my helping the poor lead to the greatest dissatisfaction for the greatest number of beings, then helping the poor is considered wrong.

The second moral theory is deontological ethics, also known as Kantian Ethics. According to Kant, an act should be performed as a result of the free decision of a rational being acting upon universal moral laws based on reason. Moral acts should be the coherent expressions of a free rational mind, which creates moral laws that take the form of Categorical Imperative (CI): "act as to treat humanity, both in your own person, and in the person of every other, always at the same time as an end, never simply as a means [3]." The $\mathrm{CI}$ is a maxim that makes a rational demand that we respect other rational beings and not use them in ways they would not consent to. Right acts and wrong acts, accordingly, are those that can become universal moral laws without leading to contradiction. For example, imagine a moral community in which the universal maxim "I will cheat for personal benefit," is a universal law. It seems obvious that irrationalities will ensue. Hence, cheating for personal benefit (also killing and lying) is universally immoral.

An alternative approach to morality is virtue ethics [4]. Virtue ethics differs from deontology and utilitarianism in that it does not provide hard and fast rules of moral conduct. Some virtue ethicists argue that it is unrealistic to expect such rules [5]. Rather, virtue ethics is primarily focused on good moral character, "Do what is honest/charitable; do not do what is dishonest/uncharitable" [6]. It suggests that it is not fruitful to try to formulate universal moral rules or calculating the right action on the basis of which consequences maximize aggregate utility. Rather, knowing right from wrong requires first cultivation of our moral character. We should acquire virtues such as temperance, justice, and compassion, and practice temperate, just, and compassionate acts, at the right time and for the right reason. The idea of virtue, however, was found to have theoretical problems: What exactly are these virtues? How do we acquire them? What should we do if different virtues conflict because they point in opposed directions? [7]. In the early modern period, the utilitarianism of Jeremy Bentham and the deontology of Kant allegedly offered overshadowed virtue ethics and led it to its decline [8].

Space here does notallow for a detailed critique of utilitarianism and deontology (or a defense of virtue ethics) [9]. Suffice it to say that many moral philosophers have found them defective and suggested abandoning such views and moving toward a virtuebased approach. Moral philosophers aside, perhaps one of the most telling problems for utilitarianism, if adopted, is that it would justify as morally good many acts that virtually all would regard as 
immoral. For example, it can justify punishing an innocent person or enslaving a small group of people in the name of the greatest good for the greatest number. But certain acts are clearly immoral regardless of how much utility they can produce. Deontology does not seem to fare any better [9]. If adopted, it would be difficult to comply with it. What happens when you have to choose between two competing maxims? For example, imagine that an innocent person is hiding from a murderer and I know where he is hiding. Should the murderer asks me if I know where that person is hiding, do I have an obligation to protect his life and lie to the murderer or do I have an obligation to tell the truth?

It seems that deontology and utilitarianism work in theory but fail in practice; while virtue ethics may have theoretical difficulties but works in practice [4]. Our moral outlook toward the environment, I want to suggest, has been shaped by deontic and utilitarian principles. Those theories make us view nature as a means to our ends. They make us wonder about our duty toward nature or the rights of nature or even which actions will maximize overall utility. If we begin our discussion on this line, we find ourselves arguing abstractly about duty, right, or utility; and we often miss what is important aspects of morality, such as care, relationship, and our internal motives that spring from our character. It is not surprising that we currently face an environmental crisis. If the virtue ethics approach is right, we should abandon deontic and consequentialist principles and do what we can to acquire those virtues, and teach them to our children, in the hope that future generations may revert the environmental damage that has already been done.

One of the central open problems of environmental ethics is how to justify our obligations to respect nature. We all believe (I hope) that it is wrong for human beings to pollute and destroy the natural environment and to waste natural resources-but wrong it what sense? Is it because a sustainable environment is essential to human well-being? Or is it wrong because nature has intrinsic value that ought to be respected? John Nolt notes that many arguments that try to show us that we have certain obligations toward nature rely on a conception that nature is a good. Each good that we find in nature is a good for some natural entities. Adequate sunlight is a good for photosynthetic plants; preferencesatisfaction may be good for a sentient being that has desires; reproductive success is (up to a certain point) good for a species... But why should the goods of those entities obligate us? [10]. One issue in particular is intensive animal farming because it is harmful to the environment. According to the United Nations, a global move toward a plant-based diet is necessary to "save the world from the worst impacts of climate change [11]." A considerable amount of global greenhouse-gas emission is caused by animal agriculture [12]. Also, growing crops to feed to animals, cleaning pollution from factory farms, and satisfying animals' thirst require an enormous amount of water. A single cow can drink up to 50 gallons of water per day, and double that amount in hot weather [13]. And according to the USGS Water Science School, "About 460 gallons for $1 / 4$ pound of beef, or about 1,750 liters per 113 grams" of water are required [14].

The number of animals raised for food produces waste that pollutes our waterways. Also, pesticides, chemicals, fertilizers, hormones and antibiotics used in animal agriculture degrade the environment. The runoff carry bacteria and viruses contaminate groundwater [15]. Furthermore, using land to grow crops to feed animals is inefficient. It takes almost 20 times less land to feed someone on a plant-based diet than it does to feed a meateater since the crops are consumed directly instead of being used to feed animals. According to the U.N. Convention to Combat Desertification. In India, annual grain consumption per person amounts to around 400 pounds per year, while in the United States, it is 1,500 pounds. It is crucial to understand that of these 1,500 pounds, only 300 pounds are directly consumed as bread, cereals or pastry. The great bulk of the rest is used for meat production. While three pounds of grain are needed to produce a one-pound gain in live weight of pigs, seven pounds are needed for a onepound gain of a cow's live weight [16].

Raising animals for food has caused, and continue to cause, ecological disasters. What we need to avert this, I believe, is the adoption of a different moral outlook. Neither utilitarianism nor deontology can account for the wrongness of wantonly destroying our environment [17]. What I propose is that change in our attitudes toward nature will come from a different approach to morality. It is more profitable, then, to address these practices by recognizing what is wrong with our moral character. The practices described above stem from the vices of greed, self-indulgence expressed by a defective moral character. The satisfaction of aggregate preference, duty, and rights, no doubt, are important moral aspects; but without the acquisition of virtuous character it is like putting the proverbial cart before the horse: we are not likely to produce the results that other theories try to achieve by starting from the questions of what actions will maximize utility or what is my duty and the right action.

One aspect in particular of virtue ethics that enables us to see what is vicious about some of our attitudes toward nature is what Aristotle calls the crown of the virtues, that is, greatness of soul, which he discusses in the Nicomachean Ethics, Book IV.3. A great-souled individual possesses great moral qualities, such as compassion, temperance, and a sense of what is right or wrong in a given circumstance. A great-souled individual is "the sort of person to do good," and "it would be quite unfitting [for such an individual] to run away with his arms swinging, or to commit an injustice" [18]. The kind of picture we get of the great-souled individual is a magnanimous, and just individual who cares about others and who "tends to produce or to preserve happiness" [19]. Being just means to avoid actions in accordance with vice, such as wanton violence [19]. It would seems plausible, then, that given the potential harm to the environment caused by intensive animal farming, a great-souled person will, for example, avoid the products of intensive animal farming. 
The foregoing discussion, however, barely begins to address the issue. What I tried to accomplish, at least, is to propose we start thinking about our relationship with the environment from a virtue-oriented approach. Such an approach is not focused on the utility of exploiting animals or destroying the environment or on the putative rights of those entities. Rather we should pause and ask what sort of person would allow the destruction of the environment. As I suggested, the sort of person who allows this is shortsighted and greedy, that is, a vicious person. The kind of magnanimous individual is, on the other hand, sensitive and aware of how much we are part of nature rather. If we acquire the virtues, we change the way we relate to the environment, and consequently change the way we treat it.

\section{References}

1. Hursthouse Rosalind (2007) Environmental Virtue Ethics. In: Rebecca L Walker \& PJ Ivanhoe, (Eds.), Oxford University Press, UK. Pp: 155172.

2. The definition of "good" may be happiness, pleasure, or satisfaction of preferences depending upon the type of utilitarianism: Act and Rule Utilitarianism. Internet Encyclopedia of Philosophy.

3. Kant Immanuel (1993) Grounding for the Metaphysics of Morals. In: Ellington James W, ( $3^{\text {rd }}$ Edn), Hackett, UK. Pp. 30.

4. Crisp Roger, Slote Michael (1997) Virtue Ethics. Oxford University Press; 1 edition, UK. pp: 304.

5. Frede Dorothea (2013) The Historic Decline of Virtue Ethics. In: Daniel C Russell, (Eds.), The Cambridge Companion to Virtue Ethics, Cambridge University Press, USA. pp: 124.

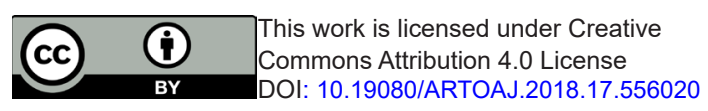

6. Hursthouse Rosalind (1999) On Virtue Ethics. Oxford University Press, UK. Pp: 275.

7. Rosalind Hursthouse, Glen Pettigrove (2003) Virtue Ethics. Stanford Encyclopedia of Philosophy.

8. Russell C Daniel (2013) Virtue Ethics in Modern Moral Philosophy. In: The Cambridge Companion to Virtue Ethics, Cambridge University Press, USA. Pp: 14.

9. Anscombe GEM (1958) Modern moral philosophy. Philosophy 33(124): 1-19.

10. Nolt John (2006) The Move from Good to Ought. Environmental Ethics 28(4): 355-374.

11. (2010) Assessing the Environmental Impact of Consumption and Production. UNEP. Pp: 1-112.

12. Premack Rachel (2016) Meat is Horrible. The Washington Post, USA.

13. (2016) Institute of Agriculture and Natural Resources. University of Nebraska-Lincoln, USA.

14. (2016) The water content of things: How much water does it take to grow a hamburger? USGS.

15. (2018) National enforcement initiative: Preventing animal waste from contaminating surface and ground water. The U.S. Environmental Protection Agency.

16. (2014) UN Convention to Combat Desertification. Which other factors lead to land degradation?

17. Alvaro Carlo (2017) Ethical Veganism, Virtue, and Greatness of the Soul. Journal of Agricultural and Environmental Ethics 30(6): 765-781.

18. (2000) Aristotle, Nicomachean Ethics, trans. Roger Crisp, Cambridge: University Press, USA. Pp: 23.

19. McDowell John (1979) Virtue and Reason. Monist 62(3): 331-350.

Your next submission with Juniper Publishers will reach you the below assets

- Quality Editorial service

- Swift Peer Review

- Reprints availability

- E-prints Service

- Manuscript Podcast for convenient understanding

- Global attainment for your research

- Manuscript accessibility in different formats

( Pdf, E-pub, Full Text, Audio)

- Unceasing customer service

Track the below URL for one-step submission https://juniperpublishers.com/online-submission.php 